\title{
A Clinical Analysis of Financial Crises
}

Citation for published version (APA):

Candelon, B. (2008). A Clinical Analysis of Financial Crises. Océ.

https://doi.org/10.26481/spe.20080919bc

Document status and date:

Published: 19/09/2008

DOI:

10.26481/spe.20080919bc

Document Version:

Publisher's PDF, also known as Version of record

\section{Please check the document version of this publication:}

- A submitted manuscript is the version of the article upon submission and before peer-review. There can be important differences between the submitted version and the official published version of record.

People interested in the research are advised to contact the author for the final version of the publication, or visit the DOI to the publisher's website.

- The final author version and the galley proof are versions of the publication after peer review.

- The final published version features the final layout of the paper including the volume, issue and page numbers.

Link to publication

\footnotetext{
General rights rights.

- You may freely distribute the URL identifying the publication in the public portal. please follow below link for the End User Agreement:

www.umlib.nl/taverne-license

Take down policy

If you believe that this document breaches copyright please contact us at:

repository@maastrichtuniversity.nl

providing details and we will investigate your claim.
}

Copyright and moral rights for the publications made accessible in the public portal are retained by the authors and/or other copyright owners and it is a condition of accessing publications that users recognise and abide by the legal requirements associated with these

- Users may download and print one copy of any publication from the public portal for the purpose of private study or research.

- You may not further distribute the material or use it for any profit-making activity or commercial gain

If the publication is distributed under the terms of Article $25 \mathrm{fa}$ of the Dutch Copyright Act, indicated by the "Taverne" license above, 


\section{oratie \\ Maastricht University \\ Bertrand Candelon \\ A clinical analysis of financial crises}

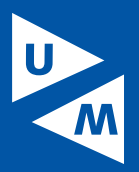



A clinical analysis of financial crises 


\section{Colofon}

Ontwerp en print: Océ Business Services, Maastricht

ISBN: $978-90-5681-292-8$

NUR: 780

Alle rechten voorbehouden. Niets uit deze uitgave mag worden verveelvoudigd, opgeslagen in een geautomatiseerd gegevensbestand of openbaar gemaakt worden, zonder voorafgaande schriftelijke toestemming van de auteur of uitgever. 


\section{A clinical analysis of financial crises}

\section{Oratie}

In vrije vorm uitgesproken bij de aanvaarding van het ambt van hoogleraar Internationale Monetaire Economie aan de Faculteit der Economische Wetenschappen en Bedrijfskunde van de Universiteit Maastricht.

Op 19 September 2008

door

Bertrand Candelon

\section{Maastricht University}


Mijnheer de Rector Magnificus, Geachte collega's, Dames en Heren,

Since the beginning of 2008, world economies have suffered from strong financial strains, producing the collapse of the real estate market in the United States, the destabilization of the international banking system (e.g., the financial distress of Northern Rock and the bankruptcy of several US banks'), the downward trend of world stock markets and a general pessimism in many economic agents. As is usual in such a case, numerous alarmist articles have been published in the press, announcing the big wave that would definitively kill or at least seriously injure our capitalist world. For example, the Financial Times published, on January 22, 2008, an article by George Soros describing the recent crisis as the worst one in 60 years. This statement was immediately reinforced by the chairperson of the Soros Fund Management, who added, "[t]he danger is that the resulting political tensions, including US protectionism, may disrupt the global economy and plunge the world into recession or worse."

When looking back at the history of economics, it appears that financial turmoil has always existed. Kindelberger (2000) has provided an exhaustive list of the crises that have hit the world's economies beginning with the famous "tulip mania" episode. It was the first speculative attack, on the tulip market in Haarlem around 1636, leaving the Dutch government in serious trouble for financing the Thirty Years War.

It is also obvious that financial crises have had a strong and deep impact on public management and, more generally, on economic theory. The origin of modern macroeconomic theory is generally associated with the publication of "The General Theory and Employment, Interest and Money" by John Maynard Keynes in 1936. In reaction to the Great Depression and its disastrous consequences for the world's economies (unemployment and deflation in particular) in the early 1930's, Keynes provided justification for government's intervention, designing macroeconomics as the framework for defining optimal instruments to cure the real effects of a crisis (unemployment and deflation in particular) and, more generally, any disequilibrium. Hence, in the aftermath of the Keynesian rupture, the role of the economist has changed from that of a neutral observer, analyzing the adjustments of prices and goods on the market and, in the end, advocating for a "laissez-faire" policy, to that of a more active player, who should optimally intervene immediately. It is worth mentioning that this active role of the economist has motivatseveral generations of students, one of which I belong to. 
Financial crises have also highlighted the obligation of macro-economics to international efforts. The last 50 years have seen a tremendous rise in the economic and financial links of economies. This evolution is mainly due to the strong decrease in trade tariffs, which used to be the traditional tool for protectionism. In the aftermath of the Bretton Woods agreement, which formed the basis of the General Agreement on Tariffs and Trades (GATT) (now called the World Trade Organization) and the numerous regional agreements (such as the Maastricht Treaty for European countries), capital controls have been almost fully removed around the world. Similarly, trade tariffs have turned out to be much lower than they were before the Second World War. This process, oftenlabeled "globalization," has had severe consequences for financial crises and the design of optimal macroeconomic policies to cure them. In particular, financial crises are no longer bound to a particular country but are transmitted worldwide at a greater pace. The recent Asian crisis is an interesting example of such a phenomenon, often called contagion. A shock occurring in Thailand is transmitted to the whole Asian area within the same year. Consequently, an optimal reaction should not be national but should be coordinated at a regional level or, even better, at the world level and rely on the institutions composing the International Monetary System.

The field covered by International Monetary Economics is vast. It runs from the analysis of financial crises to their transmission, the design of optimal macroeconomic policies, the organization of international financial structure, trade analysis and so on. Different methodological approaches can also be considered: using theoretical (static or dynamic) models and institutional perspectives or opting for an empirical perspective and implementing the tools recently proposed by econometrics (time series, panels). The diversity of these approaches could constitute an obstacle for a research agenda, as different approaches may lead to unconcealed conclusions. Nevertheless, even if I confess my preference for empirical work using current econometric tools, reconciling and linking these approaches strikes me as a motivating challenge, as it leads to a better understanding and a more efficient macroeconomic management. This lecture could thus take several hours or even days. I have decided to remain silent on certain research topics and to focusas the title of the lecture indicates-on financial crises. I will adopt the Keynesian economic perspective, acting as an emergency doctor dealing with a patient (the world economy) who is facing a serious disease 
(financial crises). The analogy to medicine is straightforward in the case of financial crisis, especially if one remembers the name given to the recent crises: the Asian flu or the Russian cold. Moreover, I find this metaphor fits quite well this new chair at the University of Maastricht, which was created 30 years ago for the study of medicine. Moreover, medicine has always held a clear interest for me and would perhaps have been my career choice, were it not for the fact that I feel faint at the sight of blood.

\section{The symptoms}

As you know, a competent medical doctor always begins an examination with a description of the symptoms of the disease. The features corresponding to the financial crisis have thus to be specified. Checking the famous Wikipedia encyclopedia, we read that a financial crisis is characterized by a "situation" in which "money demand quickly rises relative to money supply." This definition turns out to be oversimplified, but presents the advantage of stressing two important features: First, financial turmoil is a temporary episode ("situation"). Second, it implies a problem of a lack of liquidity. To find a more detailed theoretical definition we refer to a lecture at the World Bank in 2003 given by Frederic Mishkin. He defines a financial crisis as "nonlinear disruption, during which financial markets are unable to channel funds to those with the most productive investment opportunities." Even if this definition may appear a little bit esoteric for a non-specialist, it stresses other important characteristics of a financial crisis: First, financial crises may affects several financial markets at the same time: We all have in mind that the recent 1997 Asian crisis primarily affected the exchange rate market (the collapse of the Thai Baht), whereas the recent subprime crisis disturbed the real estate market. More generally, we can consider financial crises either independently or simultaneously affecting the foreign exchange, equity, bonds, real estate, or debt markets. Second, the banking sector may also play a role in the origin and/or transmission of the crisis, as it is an intermediary per se to finance investments. For example, the subprime crisis of 2008 has increased the fragility of the banking sector, due to the strong depreciation of real property assets. The situations of Northern Rock or Bear Stearns, which were close to bankruptcy, constitute perfect illustrations of this fact. Finally, financial crises are characterized by jumps ("nonlinear disruptions"), also called speculative attacks. This indicates that, at a particular moment, agents or speculators all decide to sell their holdings in order to obtain liquidity, leading to an abrupt change in the assets' prices. 
Even if these definitions provide us with a better understanding of the concept of financial crises, an operational rule that will help the economist doctor to determine if economies are facing a crisis still has to be defined.

We can start by looking at Figure 1, representing the daily evolution of the Dow Jones, the CAC 40, and the FTSE100, three well-known global indices of the New York, Paris, and London Stock Exchanges, respectively. Global indices represent a weighted average of the shares of a large number of firms from all sectors of the economy. They should thus signal that a financial crisis is occurring, whatever the market involved. The left panel of Figure 1 reports the evolution of the indices, whereas the right one reports the return (growth rate) of the stock indices. From the series in levels, it is hardly possible to detect speculative attacks, except perhaps in 2001 or 1997. Instead, it is noticeable that stock markets are subject to recurrent periods of "bulls" and "bears." 2 Typically, they can be associated with speculative bubbles (e.g., the dot.com bubble that affected the high technology sector during the 1990's), indicating that the stock index deviates from its fundamental price. Nevertheless, in no way can they be the signal of a financial crisis, since the explosion of the bubble turns out to be linear and not characterized by jumps. ${ }^{3}$

The analysis of the returns is more interesting. The variations at the beginning of the sample are predominant and to correspond to the 1987 crash. You can see that stock markets show volatility clusters (with huge variation) around 2001 and 2007 . Nevertheless, it is not possible to fix an a priori threshold beyond which excess volatility would indicate the occurrence of a crisis. Moreover, the so-called financial crisis that was supposed to have hit the world in January 2008 is difficult to detect.

Even if stock market data are used in many studies, they may not be fully adequate to detecting the tension that may occur on one particular market during a financial crisis. We can now analyze the most adequate indicator of a financial crisis market by market.

2 See Candelon, Piplack and Straetmans (2008) for recent work on this topic.

3 Some authors call this phenomenon a "long-term crash," but this terminology seems inadequate and in opposition with the theoretical definition of a crisis, which has to be of both sudden onset and limited in time. 
Figure 1:

Stock exchange indices (weekly frequency extracted from DataStream).
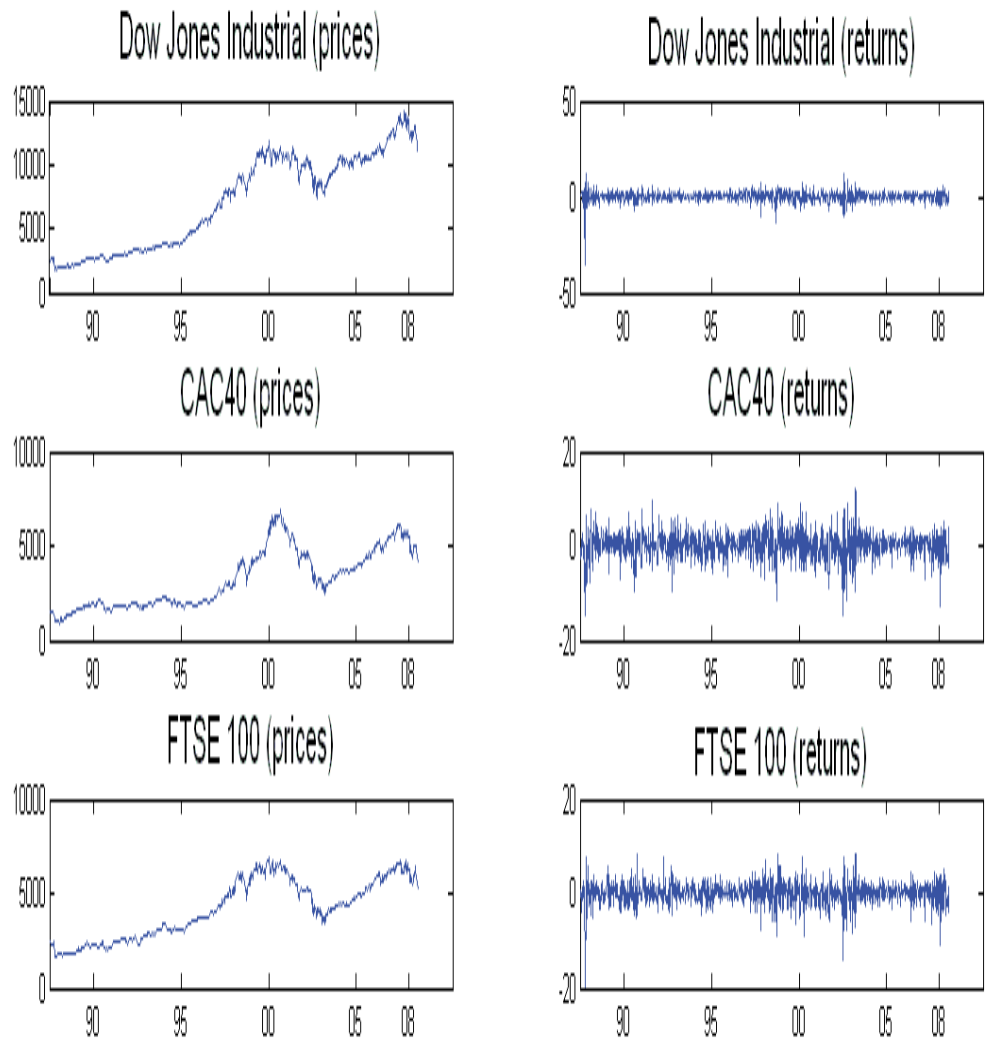


\section{Currency crisis}

To better understand the functioning of the exchange rate markets that determine the relative value of a currency vis a vis others, it is necessary to go back to the end of the Second World War In 1944, when the victorious countries signed the Bretton Woods treaty, which aimed at reorganizing the International Monetary System in order to avoid major financial disequilibria such as the 1929 financial crisis. To oversimplify the message of the treaty, all the currencies were set to have a fixed parity, and the countries' central banks could use as reserve currencies either the USD or gold (the convertibility between USD and gold being guaranteed by the US government at a fixed rate of $\$ 35$ per ounce). Additionally, a new international organization, the International Monetary Fund (IMF), was created to ensure the smooth functioning of this new system.

The choice was made for a fixed parity system in order to provide the international monetary system with credibility and stability: Hence, an investor could choose the market in which to invest, without having to consider the potential loss in terms of currency depreciation. Nevertheless, at the same time, it forced the countries to condition their internal goals (unemployment, inflation, etc) to the satisfaction of this external constraint.

The exchange rate system designed by the Bretton Woods Treaty was characterized by the fixity of the exchange rate system, but in an asymmetric way. The United States was designated as the country possessing the international reserve currency. The gold supply being limited, it was expected that the demand for USD would grow. Moreover, the United States, as the leader of the International Monetary system, was in a way obliged to provide the other countries with enough liquidity to finance the cost of the war. Japan, Germany, and some European countries benefited from the Marshall Plan to rebuild their destroyed infrastructure. The United States had the privilege of printing money to satisfy their internal goals (mainly in terms of unemployment) without taking care of the potential repercussions on other currencies. In the case of persistent disequilibrium (i.e. when the fixed exchange rate is constantly over- or under-valued, or characterized by an in or outflow of reserves in the balance sheet of the central bank), the IMF should intervene by imposing adjustments (re- or devaluate) to reach the adequate parity between the currencies under scope.

As Mr. Triffin noted, the international reserve role played by the US dollar itself contains the roots of its collapse. Indeed, since the US is in 
charge of the liquidity of the International Monetary System, they have increased monetary supply, leading to a loss of credibility in the fixed parity between the USD and gold. Moreover, countries with a persistent misalignment of their currencies (in particular, Japan and Germany presented a structural surplus in their balance of payments) were not always keen on appreciating their currency. In August 1971, Richard Nixon acknowledged that the US government could no longer guarantee the \$35 per ounce parity, leading to the collapse of the Bretton Woods system. Since then, currencies have been free to float.

At the same time, regional agreements have been signed to limit the fluctuations of the currencies. The most famous ones are the different agreements (Exchange rate mechanism, European Monetary system, and the Euro) among European countries. Looking at the classification proposed by the IMF, in May 2006,4 70 countries out of 187 presented a more or less fixed exchange rate system.

Let us come back to the symptoms of a financial crisis affecting the currency market. If the exchange rate is fixed, the occurrence of a financial crisis is easily detectable, since it coincides with the abandonment of the peg. To illustrate this characterization, Figure 2 represents the evolution of four different (nominal) exchange rates (Thai Baht, Russian Ruble, Brazilian Real, and Turkish Lira) vis à vis the USD. The period of the exchange rate peg is characterized by a linear evolution of the currency. In Thailand the crisis occurred at the end of 1997, and the local currency lost more than $50 \%$ of its value in USD. The depreciation, which followed the abandonment of the peg, was even higher for the Russian Ruble in August 1998, as it jumped from \$5/RR to \$25 some days after. Similar non-linear disruptions are also evident for the Brazilian Real in 1998 and the Turkish Lira in 2001.

In the case of a floating exchange rate system, the detection of a crisis is much more difficult. Glick and Hutchinson (1999) define a crisis as "large changes in some indicators of actual or potential currency values," but they do not provide an operational criterion to detect a crisis. For such a reason, several criteria - $25 \%$ depreciation in the nominal exchange rate, an increase in the real interest rate, etc. ${ }^{5}$ - have been used.

Another problem associated with the detection of a currency crisis is the inclusion of unsuccessful speculative attacks. It is indeed evident that a country can react to speculative pressure on its exchange rate by increasing its interest rate: in such a case, investments are attracted to the country, leading to an increase in the demand for local currency 
and appreciating the exchange rate. For this reason, Eichengreen, Rose and Wyplosz (1996) have proposed to build a currency pressure index composed of the exchange rate, the interest rate, and the reserves. Nevertheless, the optimal weighting of these three components is still debatable.

\section{Banking crisis}

Banking crises have become popular this year, with the near failure of Northern Rock and Bear Stearns and the decrease in the benefit of banks due to their potential loss of their real estate investments or the governance problem encountered by Société Générale. In fact, banking crises are inherent to the specificities of banking activities per se. To oversimplify again, banks are financial intermediaries that collect liquidity from several sources and invest it in loans with different maturity. This maturity transformation is at the origin of two potentially serious problems.

Figure 2:

\section{Nominal exchange rate vis à vis of the US Dollar}

(daily frequency extracted from DataStream)
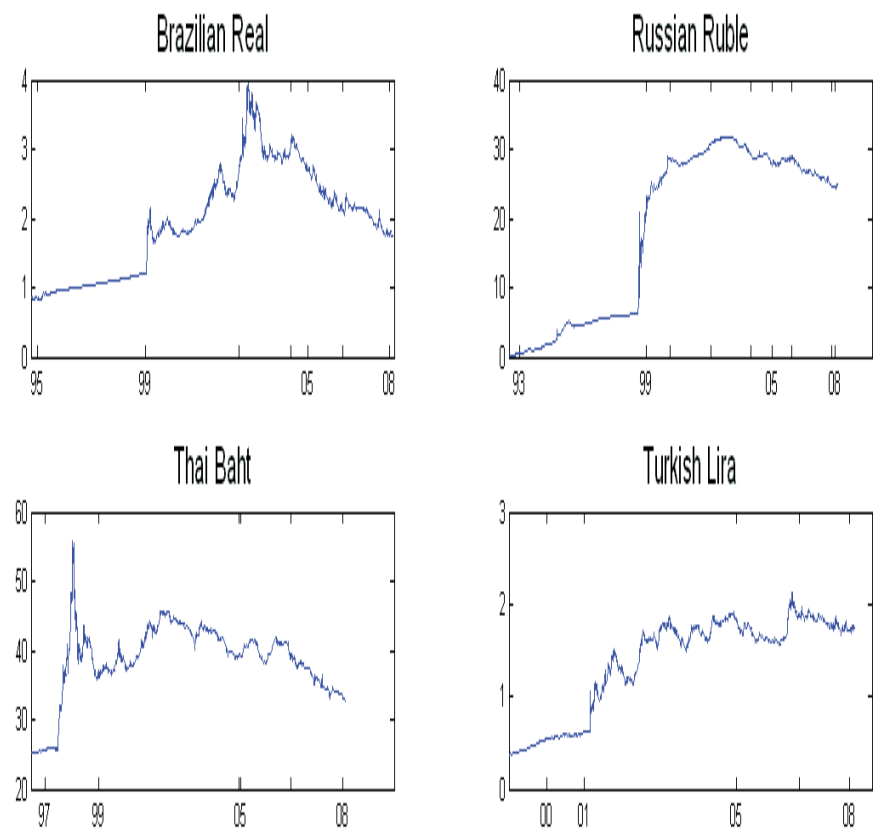
First, this transformation may lead to bank runs or panics "when a bank cannot honor its immediate contractual obligations to its creditors, even though its net value is positive. That is, it does not have funds to meet the withdrawal of deposits at a given point in time, although over time it would be able to do so" (Kumar, Masson, and Miller, 20oo, p. 4). Typically, creditors do not think that their bank can immediately pay all of its deposits; they thus decide to rush in order to be the first to withdraw their deposit, hoping that-as in a queuing system - the first in will have a higher chance to be served. That is the reason long queues formed in front of the bank agencies of Northern Rock at the beginning of this year. Bank runs are, then, associated with liquidity shortage and with loss of creditor confidence in the banking system.

The second and more serious problem is the possible insolvency aspect of a banking crisis. Take, for example, the big crisis of the 30's and the failure of the Austrian bank "Kredit-Anstalt" announced on May 11, 1931, which ruled out the economic and political stability of Central Europe. Unfortunately, such examples are not infrequent (consider the 1998 Russian crisis or the 2001 Turkish crisis).

Nevertheless, using bank runs or bankruptcies as operational indicators of a banking crisis would result in detecting only very few cases. For example, in the case of Bear Stearns, there was neither a problem of liquidity nor one of insolvency, since it has been bought by J.P. Morgan. Therefore, the previous measure would fail to detect a banking crisis in such a case, and it sounds more accurate for an empirical or operational goal to set up a measure representing the fragility of the banking sector, the crisis being detected when this index crosses a certain threshold. The implementation of such a strategy requires a maximum of information to be contained in the bank's balance sheet. ${ }^{6}$ Due to data limitation and the reluctance of banks to open their accounts, there is no consensus on the optimal set of variables that should be used. Nevertheless, all studies include a variable that represents the bank's ability to correctly price the risks associated with their intermediate role. Detragiache and Demirguc-Kunt (1998) consider the ratio of nonperforming loans (loans that are in-or nearing-default) to total bank loans. If this ratio becomes too high, it indicates that the banking system is weak: a shock will cause a bank panic and the possible insolvency of the banking sector. Typically, in the beginning of the year, non-performing loans associated with real estate investments led to a higher fragility of the banking sector in the United States.

It results from this index that almost all countries have suffered from a banking crisis since the end of the 1970's (see Figure 3). Nevertheless, 
it is noticeable that emerging countries are much more often subject to such episodes than developed ones. Typically, more than a dozen strong banking crises have occurred in developing countries (Venezuela, 1994; Mexico, 1995; Argentina, 1980-82; Chile, 1982-85; Côte d'Ivoire, 1988-91). This can be explained by the important financing role of the banking system when financial markets are not sufficiently mature.

Figure 3:

\section{Geographical localization of the episodes of banking crises since the late 1970's.}

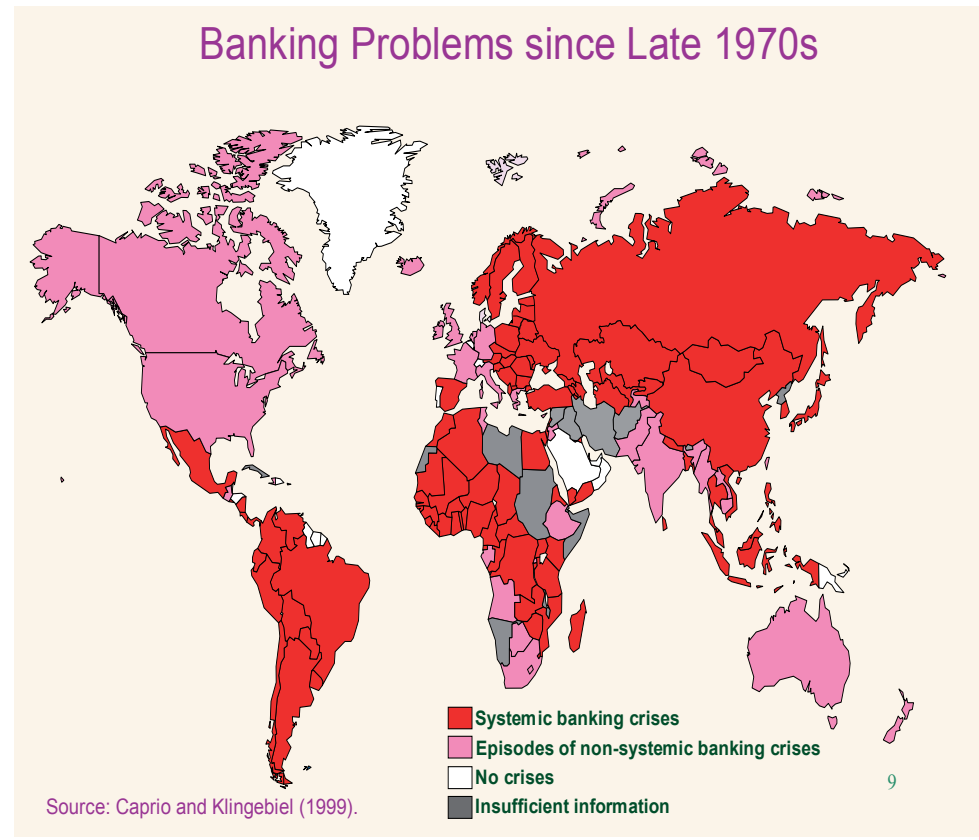

6 Bruinshoofd, Candelon and Raabe (2008) consider, for example, 15 series extracted from the balance sheet of the bank as funds competition, trade competition, bank assets, private credit by banks, bankdeposits, domestic credit by banks, overhead costs, net interest margin, claims on the private sector, claims on the government, bank liquid reserves, lending boom, foreign bank penetration, foreign assets price risk, loans to deposits and foreign funding. 


\section{Debt crisis}

A debt crisis typically occurs when a country is facing problems with the payment of the interest or the principal of its foreign debt. In other words, during a debt crisis, the country faces a liquidity problem like $a$ part entière household. Nevertheless, it is much easier for a creditor to claim a payment from individuals than from a state. This principle of sovereign immunity, which has interested lawyers for years, has been at the origin of famous military interventions before World War I (such as the British, French and Spanish intervention in Mexico in 1859-1861 and the U.S. interventions in the Dominican Republic in 1905 and in Nicaragua in 1911-12) and numerous scandals (such as the Bolshevik government's refusal to guarantee Russian loans issued by the czarist government). Since the end of the Second World War, government debt has, most of the time, been subject to commercial laws (for example, in the United States the Foreign Sovereign Immunities Act of 1976) and often traded on specific sovereign bond markets, even if all risk of spoliation has not disappeared, as the Russian crisis of 1998 showed. ${ }^{7}$

Again, such a definition of debt crisis is much too vague and does not function as an operational tool to detect a debt crisis, even if it has the advantage of providing the reader with a better and more simplified understanding. Defining a debt crisis as a period of interest rate default for a specific country would detect only a few crises, as most of the countries facing such a problem renegotiate or postpone their debt. In practice, countries rarely announce that they are officially defaulting, since the consequences for their credibility would be disastrous. According to Moody's Investors Service (2003), only seven rated sovereign bond issuers would have defaulted on their foreign currency-denominated bonds since 1985 , and all those defaults happened between 1998 and 2002. For example, the famous Mexican "crisis" in 1994-95 would not have been labeled a debt crisis, despite the substantial IMF assistance.

Moreover, this definition does not take into account the development of sovereign bond markets, which occurred in the 9o's. It is relatively easy for a country facing debt-servicing difficulties to access this specific market and to issue bonds to cover its liquidity problem. Nevertheless, a country with a high risk of default should reward investors with a consequent risk premium, leading to a higher interest rate. Again, the similarity with a household is straightforward: if you ask for a loan and show the bank that you have enough financial capacities to pay it back, the cost of the loan will be low. For such a reason, Pescatori and Sy (2007) use the bond

7 The default of the government bond (GKO) occurred in August 1998. Foreign investors then had the choice between receiving three.5\% in cash, $6.5 \%$ in a 3-month period, and $90 \%$ in new government bonds (OFZ) or $90 \%$ in new OFZ. 
spread between risky and less risky countries as an indicator of tension on the sovereign bond market. Once this spread crosses a certain threshold, a debt crisis is detected. Using this criterion, the number of crises jumps to 168 for the period $1975-1993$ ! These findings are similar to those of the famous Standard and Poor's classification. (See Table 1.)

It is also possible to include macroeconomic variables in order to build a more informative index for debt crises. Intuitively, if a country expects an improvement in its macroeconomic activity (for example, higher output, more exports, and larger tax incomes), temporary payment problems do not necessarily induce a debt crisis.

Detragiache and Spilimbergo (2001) decided to complete the information set by including ex post variables such as the rescheduling or debt restructuring agreement with commercial creditors. Nevertheless, such series are only provided with delay (of several months) and thus only permit an ex post detection of debt crises.

Table 1:

Debt crisis dates. Extracted from Pescatori and Sy (2007), p. 321.

\begin{tabular}{|c|c|c|}
\hline Country & PesSy ${ }^{1}$ & Default (S\&P) \\
\hline Algeria & $1994-96,1999$ & $1994-96$ \\
\hline Argentina & $1995,2001-02$ & $2001-02$ \\
\hline Brazil & $1994-95,1999,2002$ & 1994 \\
\hline Côte d'Ivoire & $1994-2002$ & $1994-98,2000-02$ \\
\hline Chile & No crisis & No crisis \\
\hline China & No crisis & No crisis \\
\hline Colombia & No crisis & No crisis \\
\hline Dominican Rep. & 1994 & 1994 \\
\hline Ecuador & $1994-96,1998-2002$ & $1994-95,1999-2000$ \\
\hline Egypt & No crisis & No crisis \\
\hline El Salvador & No crisis & No crisis \\
\hline Hungary & No crisis & No crisis \\
\hline Indonesia & $1998-2000,2002$ & $1998-2000,2002$ \\
\hline Korea & No crisis & No crisis \\
\hline Lebanon & No crisis & No crisis \\
\hline Malaysia & 1995 & No crisis \\
\hline Mexico & 1995 & No crisis \\
\hline Morocco & No crisis & No crisis \\
\hline Nigeria & $1994-96,1999-2002$ & No crisis \\
\hline Pakistan & $1998-99,2001$ & $1998-99$ \\
\hline Panama & $1994-96$ & $1994-96$ \\
\hline Peru & $1994 \quad 97$ & $1994 \quad 97$ \\
\hline Philippines & No crisis & No crisis \\
\hline Poland & 1994 & 1994 \\
\hline Russia & $1994-2000$ & $1994-2000$ \\
\hline South Africa & No crisis & No crisis \\
\hline Thailand & No crisis & No crisis \\
\hline Tunisia & No crisis & No crisis \\
\hline Turkey & No crisis & No crisis \\
\hline Ukraine & $1998-2001$ & $1998-2000$ \\
\hline Uruguay & No crisis & No crisis \\
\hline Venezuela & $1994-97,1999,2002$ & $1995-97$ \\
\hline
\end{tabular}


It is obvious from this quick descriptive survey that the theoretical symptoms of financial crises are many and depend on the type of crisis (currency, banking or debt). Moreover, even if theoretical definitions are available and generally accepted, an unambiguous operational criterion, which could be used to detect the occurrence of a certain type of crises, is not available. It is interesting to note that, in this field, theory seems to still be ahead of practice.

\section{Several types of crises, one example: the Russian cold 1998}

Unfortunately, several types of crises could simultaneously hit a country during the same historical episode. Typically, a currency crisis can occur together with a banking crisis, creating a "twin crisis." Of course, a debt crisis leading to the potential default of the country may also be associated with a twin crisis, leading to severe financial "disease". The best way to illustrate this with an historical example, in my opinion, is with the Russian turmoil of 1998 (also labeled the Russian cold), which constitutes the best illustration of a global crisis associating banking, currency, and debt crises.

On October 27-28, 1997, the Russian stock exchange sharply collapsed. While less severe, the downward trend on the Russian shares continued at the beginning of November. Noticing the crunch in liquidity and the decrease in confidence of the foreign investors in Russia, the government of Prime Minister Chernomyrdin decided to inject liquidities from November 11 onward. In December, the World Bank provided a 1.6 bilIion USD loan to the Russian government. Despite these interventions, the crisis was not stopped, simply delayed. In March 1998, the famous agency rate company Moody's downgrades the Russian long-term foreign currency debt. This signified that, despite public intervention, the crisis was still going on, and the risk of investing in Russia rose. Investors were asking for a higher risk premium, increasing thus the probability of country default. The debt crisis could then be detected. At the same time, the stock exchange reached its two-year minimum level, highlighting the severity of the crisis. Facing a potential severe turmoil and noticing the incapacity of the Prime Minister to cure the disease, President Yeltsin and the parliament decided to substitute Kiriyenko for Chernomyrdin on March 23, 1998. This decision did not structurally affect the situation as, in mid-July 1998, the IMF provided an emergency package of 22.7 Billion USD. It was then acknowledged that the situation became catastrophic and that the liquidities available were insufficient to curving down the crisis. On August 17, 1998, Russian authorities 
announced the abandonment of the peg to the USD, leading to a quasiimmediate depreciation of the Russian Ruble by 50\%, signaling the occurrence of a currency crisis. The government suspended the payment of the government bonds (called GKO), indicating that Russia could not pay the service of its debt. The debt crisis was then acknowledged. Simultaneously, a 9o-day moratorium on payment by Russian banks was announced in order to avoid the collapse of the entire Russian banking system. There was thus a great liquidity crunch in the Russian banking system, leading to the stigma of a banking crisis.

It is therefore noticeable that, at the end of the summer of 1998, the patient Russia was affected by a serious cold associating the three types of crises previously described: currency, banking, and debt crises. The symptoms were so severe that the diagnosis of a financial crisis was unambiguous. Prime Minister Kyrienko appeared to be unable to provide an adequate cure, but the candidates for this position were not numerous. On August 23, Yeltsin decided to offer the interim position to Kyrienko's predecessor, Chernomyrdin, in order to get enough time to find an adequate candidate. ${ }^{8}$ Almost ten years after the collapse of the Berlin's wall, Russia faced a second earthquake, which was not political but economical. The Russian cold constitutes an adequate example of financial turmoil, for which any operational indicators would detect simultaneously a currency, a banking and a debt crisis.

Even if the example of the Russian cold is interesting per se, one should nevertheless consider it to be specific to a country in transition or an emerging country. The probability that a similar event would occur in a developed country is low. Besides, the consequences for the real economy turned out to be negligible ex post. Some detractors would then propose to focus on more stringent and structural economic problems such as inflation or unemployment.

\section{Financial Crisis: a growing and more severe problem for the world economies}

To tackle this issue, Bordo et al. (2001) propose a deep historical analysis and investigate 1) whether financial crises have become more frequent in the recent years; 2 ) if yes, which type of crisis occurs more frequently (banking, currency or both)9; 3) whether they became more severe; and 4) whether they imply real activity loss. Several factors may explain why financial crises in general should have become much more frequent in the recent past. First, financial globalization (a decrease in transaction costs and the creation of new potential markets in emer- 
ging countries) has favored a better risk diversification, but at the same time, the mobility of capital increases, leading to a greater instability of financial markets. As is typical, after the rumors indicating that the Thai real estate market was over-estimated in 1997, risky investments were immediately withdrawn from Thailand to settle more mature markets. Similarly, the elaboration of such new financial products as complex credit derivatives and exotic credit hedges has led to dilution of risk. Many practitioners fallaciously conclude that the risk disappears, but instead it has been spread out among market participants, increasing the probability of a global financial crisis. Nevertheless, at the same time, economic education and information as well as regulation have been improved. Typically, regulation authorities have developed new tools to control for the risk taken by the banks and may intervene in cases of over-exposure of the whole banking system. At this stage, it is thus hard to say which factors are dominating. Bordo et al. (2001) consider a large set of countries -21 (resp. $5^{10}$ ) for the periods before (resp. after) 1971- as well as four periods: 1880-1913 (characterized by the gold exchange standard), 1919-1930 (interwar period with several exchange rate systems), 1944-1971 (the Bretton Woods system) and 1973-1997 (the post-Bretton Woods period). They calculate the probability over each sub-period of a particular country facing a currency and/or a banking crisis. ${ }^{11}$

8 Primakov seceded to Chernomyrdin on September 11th.

9 Bordo et al. (2001) did not consider the case of a sovereign debt crisis.

10 Emerging as well as new countries issuing from the decolonization process are then included among these 56 countries.

11 The method used to date the crises is available in Bordo et al. (2001) 
Figure 4:

From Bordo et al. (2001), p. 50

Crisis Frequency

(per cent probability per year)

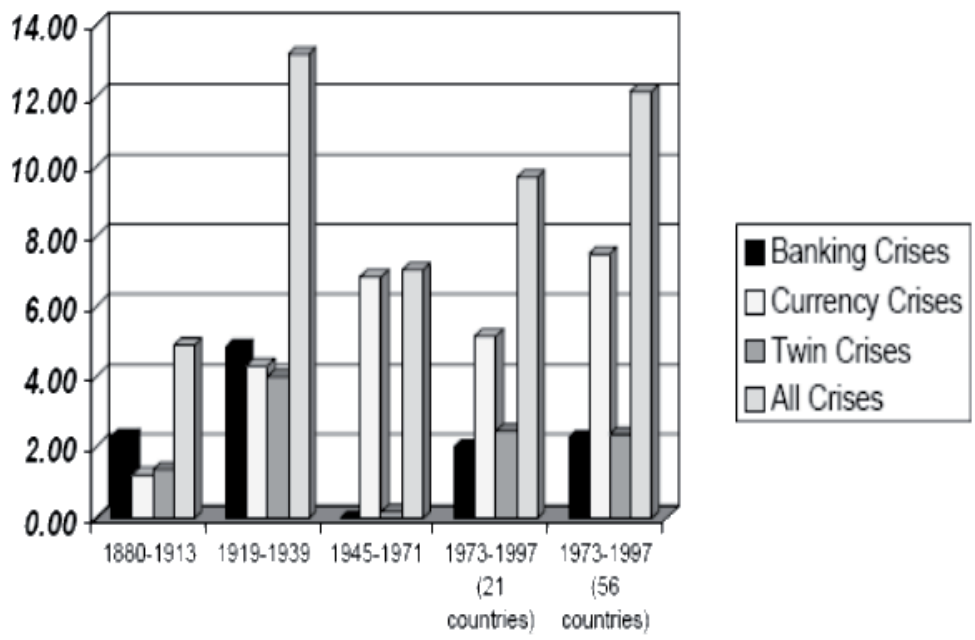

Figure 4 clearly reveals that the probability of financial crisis (whatever the type of crisis and the sample of countries considered) has been higher after the collapse of the Bretton Woods system than before. It is nevertheless noticeable that this frequency is still lower than what it was during the interwar period. When using the restricted set of countries (excluding emerging ones), the frequency of banking crisis goes down, supporting the idea that banking regulations implemented at the national or international level (Basel agreement for Europe) improved the stability of the banking sector. On the other hand, the exchange rate volatility has increased (the speculative attack of the Italian Lira and the British Pound in 1992 or the Scandinavian crisis in 1990). This reveals that, whatever the criticisms that can be addressed to the Bretton Woods system, it guaranteed the stability on the foreign exchange markets, justifying ex-post the role of the International Monetary Fund. ${ }^{12}$

The ex post probability of a twin crisis has thus strongly increased after 1971. The interpretation of this stylized fact is twofold: Either it

12 It is noticeable that the frequency of a currency crisis under the gold exchange standard was even higher. 
comes directly from the greater frequency in currency crisis, or it can be that, beyond the statistical argument, higher linkages have been created between the banking and the foreign exchange markets, leading to a greater transmission of one crisis to the other one.

Finally, considering the largest set of countries (emerging, transitional and less developed countries) leads to a rise in the prevalence of all type of crises. This is why it is usually believed that a financial crisis is a problem exclusively for the less advanced economies in the world. This statement is only partly correct, as the frequency of occurrence of a crisis in developed countries is only slightly lower than in the other countries. ${ }^{13}$

The relative increase in the frequency of financial crises may also trigger different patterns. If the crises are more frequent but less severe (because, for example, of an adequate intervention of the national authorities and the International Monetary system), it would then be possible to conclude an improvement in financial stability. On the contrary, crises may have become stronger, confirming that the problem is getting more frequent and more severe.

Pursuing their empirical investigation, Bordo et al. (2001) report the average duration of the crisis as well as the crisis depth, measured by the cumulative Gross Domestic Product loss during the turmoil.

Table 2:

\section{Extracted from Bordo et al. (2001).}

\begin{tabular}{llllll}
\hline \hline All countries & \multicolumn{7}{c}{ 1973-1997 } & 1973-1997 \\
& $1880-1913$ & $1919-1939$ & $1945-1971$ & 21-nations & 56-nations \\
\hline Currency Crisis & 2.6 & 1.9 & 1.8 & 1.9 & 2.1 \\
Banking Crises & 2.3 & 2.4 & average duration of crises in years & 3.1 & 2.6 \\
Twin Crises & 2.2 & 2.7 & 1.0 & 3.7 & 3.8 \\
All Crises & 2.4 & 2.4 & 1.8 & 2.6 & 2.5 \\
& & Average crisis depth (cumulative GDP loss in \%) & \\
Currency Crisis & 8.3 & 14.2 & 5.2 & 3.8 & 5.9 \\
Banking Crises & 8.4 & 10.5 & a & 7.0 & 6.2 \\
Twin Crises & 14.5 & 15.8 & 1.7 & 15.7 & 18.6 \\
All Crises & 9.8 & 13.4 & 5.2 & 7.8 & 8.3 \\
\hline \hline
\end{tabular}

Notes: ${ }^{2}$ indicates no crises

It turns out that twin crises are always the most costly in terms of activity loss and duration, as they combine the effects on several markets. Table 2 also shows that the cost of a banking crisis for economic

13 It is even likely that a formal test would not reject the equality between these frequencies. 
activity is larger than that of a currency crisis. Such a result can be justified by recent international economic theory, which proves that under capital control, currency crisis may not have a negative effect on activity. It is thus important for a regulatory institution to have this ranking in mind in order to intervene adequately.

Concerning the recent evolution, Table 2 shows contrasting results concerning the length and the intensity. The average duration of crises, whatever their type, seems to be longer than that observed during the Bretton Woods and the interwar periods. In contrast, the average crisis depth remains in line with the 1945-1971 period (except for the twin crisis) but turns out to be much less than the one prevailing for the interwar period. Such a result tends to indicate that the leading characteristic of the recent crises is less strength than it is longer duration.

The inclusion of emerging and transitional countries in the sample does not modify the conclusion in terms of crisis duration. On the contrary, the severity of the currency and the twin crisis becomes higher. This confirms the previous finding that avoiding currency crashes is of major importance for emerging countries.

More insight into the cost of a crisis in terms of real activity is given by Hutchinson and Noy (2006). Using an elaborated econometric model ${ }^{14}$ for a sample of 24 emerging countries, they find that on average real output growth declines about $1.3 \%$ in the year a currency crisis takes place. The year after the recovery is slight but significant (around 0.3\%). The recovery is complete two years after the event. Disentangling the different types of crises, they confirm the results of Bordo et al. (2001). In the case of a currency crisis, output growth is reduced by only $0.5 \%$ the year of the crisis and reaches its previous level one year after. The real impact of a crisis is much more important (a $4.1 \%$ fall in real output growth) and longer (the output stays depressed for the two years after the crisis) in the case of a banking crisis. ${ }^{15}$

Hutchinson and Noy (2006) also investigate the effects of financial crises on two other variables: the primary budget and inflation. They find that crises seem to have no significant direct effect on the public deficit, whereas they play an important role in inflation (currency and twin crises leading generally to an upward trend in current inflation, whereas a banking crisis puts a downward pressure on price movement).

14 Formally, they consider a profit panel model.

15 This finding is confirmed by Dell'Ariccia et al. (2008), who consider a larger panel of 41 countries. They nevertheless show that the output cost of a banking crisis is greater for sectors of activity more dependent on external finance. Furthermore, the heterogeneity is much more important in developing countries. 
In any case, it is obvious that tensions on financial markets affect output growth as well as the development path of emerging countries. We recognize that the consequences are limited in times and should not in principle modify the long-term path of the economies. Nevertheless, real effects of financial crises last several years (more than two years), affecting the business cycle evolution, and may have persistent consequences for the development process of the poorest countries. It is thus necessary to propose an efficient treatment to cure this disease.

\section{Financial Crisis model and a specific treatment to each type of crisis}

As usual in medicine, the treatment applied to cure a disease depends on its underlying causes. Typically, whereas a sore throat caused by a virus just requires a good painkiller, local treatment and some patience, the same symptoms caused by bacteria should be treated more actively with, for example, antibiotics. In the case of financial crises, finding a treatment adequate and appropriate to the cause of the disease is also mandatory.

For sake of simplicity and time, we will focus exclusively on currency and twin crises, even if similar analyses for banking crises (with, of course, specific determinants) are available. ${ }^{16}$

\section{Crises due to bad fundamentals}

The first type of currency crisis justifies the collapse of a fixed exchange rate as a consequence of incoherent macroeconomic policies. Flood and Garber (1984) stress the importance of the monetary growth in this process. Rationally increasing money growth can serve in supporting the minimum wage and social advantage or creating monetary illusion (as inflation is a pure monetary phenomenon). When a central bank is issuing money at a constant rate, there is an outflow of reserves, leading to a deficit in the external position of the country (also called balance of payment). Speculators notice this evolution in the reserves, and they know at a certain time that these reserves will be exhausted. Just before the exhaustion, there is a discrete jump in reserves corresponding to the currency crises. 
Unable to maintain the peg of the currency, the government is obliged to let the exchange rate float. ${ }^{17}$ Figure 5 represents this speculative path.

Figure 5:

\section{Fundamental-based currency crisis}

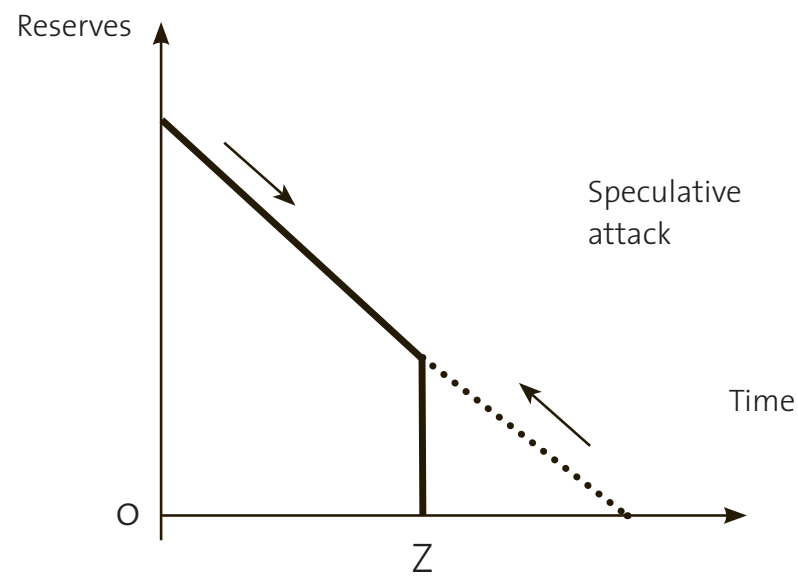

It is quite interesting to notice that this linear model succeeds in explaining the jump (pure non-linear adjustment) characterizing the speculative attack. It is also evident that the date of the currency crisis (z) depends on the initial stock of reserves (if it is very high, then the occurrence of the speculative attack is postponed) and the strength of the money growth (here it corresponds to the slope of the curve). This first generation model also stresses the importance of macroeconomic fundamentals in the determination of the exchange rate. If the fixed exchange rate is higher than the exchange rate, which should have prevailed given macroeconomic variables ${ }^{18}$ (here, the money growth variable), there is an inflow of foreign currency due to the greater competitiveness of the economy.

17 In the case of floating exchange rate, there is no inflow or outflow of reserve as the exchange rate evolution is clearing the external position of the country.

18 It is generally called the shadow exchange rate. 
The crisis occurs when reserves are exhausted, that is, when the shadow exchange rate equals the fixed one. Figure 6 illustrates this mechanism.

Figure 6

\section{Fundamental-based currency crisis}

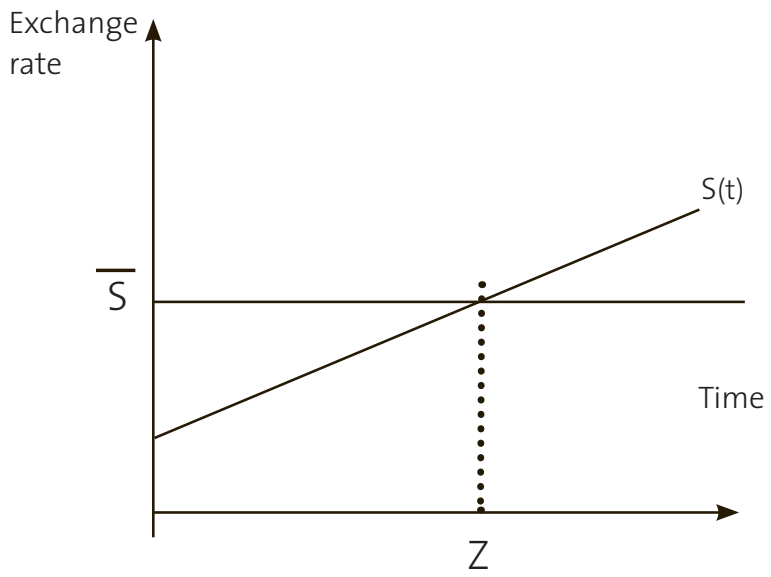

Such a model of currency crisis is "moral" in a sense. The message is clear: if a patient smokes, drinks alcohol, does not eat enough fruit and vegetables and does not practice any sport, he is likely to face serious health problems in the future. For an economy, if fundamental macroeconomic variables (money growth, inflation, public deficit) are not in line with the fixed value of the exchange rate, currency crisis is expected to occur almost surely in the future. Applied to the Russian crisis it is evident that the decrease in the price of oil has altered the Russian term of trade and limited the inflow of foreign reserves. The effect of the counter oil shock has been amplified by the huge industrial concentration of the country in the energy sector. Simultaneously, the huge public deficit caused by the transition process has also accelerated the collapse of the Russian Ruble, which could not keep its parity with the USD. Bad macroeconomic fundamentals seem then to partially explain the 1998 Russian cold. 
The treatment in such a case is straightforward and aims at restoring virtuous macroeconomic fundamentals. The patient should stop smoking and drinking alcohol, change his eating habits, and participate in sports. The personal trainer for the economy is usually the IMF, which applies its famous "cure package", consisting in curving down money supply (a decrease in minimum wage and social protection), limiting public deficit (cutting government spending and raising taxes) and liberalizing the rules for foreign investment and trade. The treatment is usually painful for the population and costly for welfare ${ }^{19}$ but usually suffices to stop the collapse of the currency.

\section{Non-fundamental-based crises}

Unfortunately, these models appear to be unable to explain recent currency turmoil. For example, the European exchange rate mechanism (ERM) was wrecked by a severe crisis in 1991-1992. The biggest victims of the ERM crisis (the UK, Spain, and France) were not undermined by weak fundamentals or inadequate monetary policies. Moreover, the exhaustion in their international reserves should theoretically have been impossible. According to the European solidarity mechanisms (expressed in particular in the Nyborg agreement in 1988), the central banks of the other European countries (in particular the Bundesbank) have to defend endangered currencies. The availability of foreign reserves is then unlimited, annihilating a priori any currency attack. Nevertheless, the speculative attack occurred, leading to a strong depreciation of these three currencies that crossed the fluctuation margins. This type of currency crisis concerns a healthy patient with virtuous behaviors (healthy, non-drinker, non-smoker, regular physical activity), who is nevertheless affected by the disease. What can be the causes behind these currency crises?

Second-generation models of crisis integrate several aspects of market psychology in order to develop a framework able to explain the occurrence of currency crisis in a healthy economy. Several origins are proposed. Let us first have a look at the 1992 ERM crisis in the United Kingdom. It is evident that the British government had imposed on itself an uncomfortable currency peg. The credibility of investors was then affected and the government had to increase the interest rates to incite foreign investors in holding assets denominated in the country's currency. Nevertheless, this action worsened the real macroeconomic

19 It is sometimes claimed that the negative effects of the treatment are worse than the disease itself: high interest rates affecting country's growth and thus employment rates. 
situation (unemployment and growth) but also led to an increase in the number of speculators attacking the currency: The reaction of the British government constituted the clear signal that something was happening. A portion of the local/small investors reacted to this signal by selling their assets in local currency. The crisis, which had been virtual, then became real. Such a self-fulfilling mechanism highlights the importance of news or rumor (whether true or false) affecting the market sentiment. Whether the country's policy is good or bad is, in this sense, irrelevant.

Several other psychological mechanisms may also lead a rumor to launch a crisis. First, as information is asymmetric (that is, not the same for everyone), investors tend to have the same behavior amplifying all the movement on the markets. If the leader (the investor having a credible reputation) goes in one direction, all others will follow without thinking. As a result, all of them may go over a cliff. Their behavior is not based on economic fundamentals but may still be justified. First, following Obstfeld (1994), it is possible to show that an investor who will not follow the masses will lose. Second, from a psychological point of view, it is more comfortable to justify a decision (correct or not) by arguing that all other people took it. An information cascade may also be observed. Typically, if a market analyst says that a particular country will face a problem, some people begin to believe it. Because some believe it, more and more people come to believe it. The information spreads over the market participants like an avalanche and cannot be stopped. It has been well documented that these phenomena occurred during the 1992 ERM. In this episode, Soros played the role of the well-informed analyst who was predicting the collapse of the British pound. His pessimism spread across the markets, leading to a self-fulfilling crisis. Similarly, Boinet, Napolitano and Spagnolo (2002) find that self-fulfilling prophecies are likely to have played a large role in the devaluation of the Argentinean peso in 2002. In such a case, a treatment aiming at improving fundamentals would make no sense, since the fundamentals are already strong. On the contrary, authorities should be persuasive and clearly state that the crisis has no chance to be successful, and then wise investors should refrain from attacking the currency. This was exactly the reaction of British authorities in 1992. Unfortunately, it took some months before the British pound stabilized, stressing the importance of a coordinated reaction at the European or at the world level.

Moral hazard may also constitute a potential origin of the crisis. Imagine that a new medicine would cure all the diseases caused by 
cigarettes and alcohol. You would then notice an increase in these pathologies. If a country is sure to be saved in case of balance of payment problem, it could be then tempted to run bad macroeconomic policies, simply to satisfy its citizens.

The transmission of a crisis affecting a neighbor or a trade partner may also be at the root of a currency crisis, regardless of the economic fundamentals. The concept of contagion is taken directly from the medical field and indicates the transmission of a contagious disease. Unfortunately, the translation to an economic concept is not straightforward, as confirmed by the numerous definitions of contagion available on the World Bank's website. ${ }^{20}$ Several authors, including Rigobon (1999) and Forbes and Rigobon (2002), define contagion as a significant and temporary increase in cross-market linkages following a shock. Contagions can jump between markets, for instance, between the foreign exchange market and the stock market, as well as across countries. This concept of contagion is often called a "shift-contagion." Imagine two patients, one affected by the flu. Their prior situations were entirely different: one weak, the other healthy. One day later, both are in the same state, lying in bed with fever. Forbes and Rigobon (2002) would conclude that the virus has been transmitted and thus there has been contagion. For these authors, contagion is simply the cross-country or cross-market transmission of shock, whether or not the linkages are reinforced. This definition of contagion is appealingly simple to implement. Nevertheless, it leads to several econometric and conceptual problems.

Varieties of econometric techniques have been used to measure shift contagions. An intuitive and widely-used technique has been to test whether the correlation between two markets was significantly higher during the period following the crisis than during the period preceding the crisis. For example, King and Wadhwani (1990) show that the crossmarket correlation between the U.S., U.K and Japan has significantly increased after the U.S. stock market crash in 1987. Calvo and Reinhart (1995) and Baig and Goldfajn (1998) use a similar approach to show the presence of shift-contagion after the 1994 Mexican peso crisis and the 1997 Asian crisis.

Nevertheless, this intuitive approach presents several shortcomings. First, correlation is a static, bivariate, and symmetric measure. It thus neglects the possible dynamic structure of the linkages and may in addition omit contributing variables. For example, if a shock in the Russian equity market is transmitted to the Mexican exchange market via the

20 See http://www1.worldbank.org/economicpolicy/managing\%2ovolatility/contagion/ definitions.html 
Brazilian exchange market, the correlation will not detect contagion. This "third effect" has to be taken into account to provide a more precise measure of the transmission of the crisis. ${ }^{21}$ Secondly, correlation automatically increases during periods of high volatility and during periods of globalization. Hence, a significant increase in the correlation coefficient after a crisis may have nothing to do with contagion, but may instead signal an increase in interdependence. Several papers have tried to distinguish contagion from interdependence, assuming that contagion should lead to a more abrupt change in the correlation than interdependence. ${ }^{22}$ Nevertheless, such an identification remains far from straightforward, and future research should consolidate the previous approach. Third, Manner and Candelon (2008) show that when you consider a more general framework (for example, a non-linear model), correlation measure is biased and leads to an over-rejection of the contagion hypothesis. For all these reasons, the evaluation of contagious effect after a crisis remains a hot and interesting domain for empirical research.

Conceptually, shift-contagion also presents some weaknesses. Masson (1999) noticed that the same virus might affect both patients without necessarily indicating a contagious effect. He proposes to file this case under "monsoonal effect." Each Asian economy sees their activity reduced at the same time when a monsoon is severe. In such a case, it is not possible to conclude the presence of contagion.

Moreover, the detection of an increase in correlation does not indicate the channel through which the virus has been transmitted. It thus makes the optimal political reaction quite difficult to set up.

For such a reason, other authors prefer to identify the channels through which shocks are transmitted. The most important are the trade channel (Glick and Rose, 1999), the financial channel (van Rickenghem and Weder, 2001), similarities between economies (Eichengreen, Rose and Wyplosz, 1996), policy coordination or geographical proximity (Bayoumi et al, 2003). Unfortunately, empirical literature ${ }^{23}$ shows that these transmission channels are very unstable across crisis and time. It is thus impossible to define a general picture of the transmission channel.

In the case of a contagious crisis, the treatment would consist of a temporary isolation of the economy. If financial flows constitute the

21 See Breitung and Candelon (2008a) and (2008b) for econometric testing of multistep causality.

22 See Candelon, Piplack and Straetmans (2008).

23 See in particular Bruinshoofd, Candelon and Raabe (2008). 
transmission channels, a strict capital control turns out to be an adequate measure. ${ }^{24}$ However, if a crisis is transmitted via trade, the situation is more difficult to handle. It is indeed almost impossible to freeze trade from infected economies, especially when they are located in the same region of the world and when free trade agreements have been signed. Glick and Rose (1999) use this argument to attribute to crises a regional dimension. Nevertheless, with a higher degree of integration, it is evident that the contagion of a crisis will be quicker and impossible to control. For example, some studies support the idea that the Russian cold had its roots in Asia and contaminated Latin America (in particular Brazil). Such a disease constitutes the major fear for market analysts and a promising research topic.

\section{The role of the banking sector.}

However, neither the first- nor the second-generation model was able to fully explain recent problems like the Asian flu or the subprime crisis. Therefore, a third-generation model is needed to complete the picture. Several attempts have been made to construct such a model. The first models, like the one produced by McKinnon and Phill (1996), consider the banking system as the core of the crises and explain the more frequent occurrence of twin crises.

Krugman (1999) synthesizes the idea under the concept of "moralhazard lending." Stimulated by competition of fast growing economies or during expansion, banks are tempted to accept much riskier loans in order to keep their benefit. This results in a larger number of nonperforming loans and a higher composition of risky assets. Therefore, an apparently stable banking sector can be in reality fragile, ready to collapse after a negative rumor or simply at the end of the expansion phase of the cycle. ${ }^{25}$

Another possible explanation for the underlying fragility of the banking sector lies in the adequate management of the maturity transformation by private banks. In order to increase their returns, banks transform short-run deposits into long-run credits, leading to the possibility of bank run (creditors who want to withdraw their deposits could not be satisfied by the banks). During the Asian flu epidemic, this problem was amplified by the fact that Asian central banks did not have sufficient currency reserves and were therefore unable to act as lenders of last resort to prevent a bank run (Chang and Velasco, 1998).

24 This has been experimented with in Brazil in 1994 and Russia in 1998.

25

This is in fact what happened at the beginning of the subprime crisis. For theoretical models, see Allen and Gale (1998). 
Third, the linkages between governments and the private banking sector can also be at the origin of the crisis. In the case of the Russian cold, the government used to finance its public deficit by issuing public bonds, as the Russian Central Bank was not authorized to issue money. ${ }^{26}$ Private banks were somehow forced to buy these bonds, leading to an extreme fragility of their balance sheet. A small negative shock thus leads to the collapse of the system and the transformation of a banking crisis into a currency crisis. ${ }^{27}$

Treatments associated with this type of crisis should be more structurally oriented, since they affect the economy at the micro level. Higher and more efficient regulations of the banking sector (see the Basle II agreement) constitute an example of a treatment to cure a thirdgeneration crisis.

Unfortunately, it is often the case that the second or even the third generation of a crisis may explain a particular episode. Coming back to the 1998 Russian crisis, it is evident that the counter oil shock and the specialization of the economy in the energy sector led to bad macroeconomic fundamentals: deficit in the balance of payment and degradation of the term of trade. At the same time, the important public deficits, necessary to speed up the transmission process, coupled with the uncontrolled emission of public bonds (GKO/OFZ) ${ }^{28}$ indicated a weak macroeconomic situation in Russia. It was also noticeable that the private banking system was quite fragile: a huge buyer of the public bonds, not deregulated enough and dependent on foreign capital. At the same time, the recent Asian crisis has signaled investors that holding assets in emerging markets was not a 100\% secure investment. Moreover, in order to cover their loss originating from this crisis, a huge part of the investors were ready to reshuffle their investment in favor of industrialized countries. All the conditions were gathered for the occurrence of a general disease after any shock. That is what happened in 1998. The cure consisted in a mixture of an austerity package (mainly cut in public expenditures), a reorganization of the private banking system (leading to a higher regulation) and an active intervention of the monetary authorities (in particular to control the value of the public bonds).

26 The rationale behind this is the fight against inflation.

27 A similar explanation can be applied to the Turkish crisis in 2001.

28

The Central Bank of Russia was not authorized by the law to print money in order to cover this public deficit. Such a decision was made in order to fight against inflation. 


\section{Prevention and Health system}

\section{Early Warning System}

As the origins of the crisis disease are set up, it could be worthwhile to create a bunch of indicators signaling in advance the probable occurrence of a currency crisis for a particular country. This Early Warning System would constitute the blood analysis of an economy, leading to a preventive and optimal reaction from the competent authorities. Doing so, we could imagine a more effective and less painful treatment of the disease.

Early Warning Systems exploit advanced statistical models. The first idea, proposed by Kaminsky, Lizondo and Reinhart (1998), consists in using a signaling approach. They consider a large set of indicators (relating the external position, the financial sector, the real sector, the institutional structure and the fiscal policy of a particular country), and when one or more of these indicators crosses a certain threshold, the model signals the probability of a future financial crisis. Berg and Pattillo (1998) show that a simple profit panel-based model strongly outperforms the signal approach and recommend the use of discrete choice techniques. More recently, Tudela (2005) and van den Berg (2008) prefer to use the properties of duration between two crises to build an Early Warning System. They show that their behaviors are superior to the existing models when the panel dimension is limited to countries exhibiting similar patterns. ${ }^{29}$

All these statistical models constitute relatively good leading indicators of a crisis caused by bad fundamentals. They could even quite correctly indicate which weak fundamental(s) has to be improved in order to avoid or at least limit the severity of the crisis. For example, in retrospect, the Mexican tequila crisis could have been quite well forecasted one year before its occurrence using the duration approach of Tudela (2004).

These models can also partially detect the possible contagion of a crisis from one country to another by exploiting the spatial dimension of the variable (see van den Berg, 2008). The whole problem consists in correctly modeling the distance between countries: Do bilateral trade, financial flows, or industry similarities constitute adequate proxies for modeling the transmission channel of a crisis? The debate remains open, since at this stage, it is not possible to integrate these three channels into a single model. Furthermore, Berg and Pattillo (1998) also show that

29 See Van den Berg, Candelon and Urbain (2008). 
the optimal horizon of forecast, the delay between when the blood test detects the possibility of a future disease and the occurrence of the crisis itself, is around one year, which is either too long (to stimulate the market) or too short (to develop adequate structural policies). A sequence of models with different forecast horizons should be available. Unfortunately, they tend to exhibit different statistical properties, leading to possible inconsistencies in the policy implemented.

At the moment, Early Warning Systems do not appear to be able to correctly detect a crisis not caused by bad fundamentals or a shiftcontagion process (as self-fulfilling prophesies). Unfortunately, such types of crises turn out to become the most frequent and consequently the most interesting to be forecasted.

It is thus obvious that at this time, statistical methods do not provide a correct blood test for delivering a reliable leading indicator of impending financial crises. All the articles in the press or sensational declarations in the media signaling the future occurrence of a crisis are inconsistent ways to stress the markets and create a self-fulfilling crisis.

\section{Health System: Reorganizing the International Monetary System}

Since Early Warning Systems are not in fact able to perfectly predict the occurrence of a financial crisis, the International Monetary System should be efficient and quick enough to isolate and cure the disease when it does happen. The International Monetary architecture appears to be quite complex; it can be separated into world, regional and national levels. The most famous world institution, the IMF, aims at ensuring the stability and the smooth functioning of the International Monetary System and the exchange rate. While this second objective was predominant before the 70's, in the recent years the IMF put its efforts towardstrengthening the international financial system and enhancing its effectiveness in preventing and resolving crises. Typically, the IMF has developed and offered to member states macro-prudential indicators similar to Early Warning Systems, aimed at preventing first-generation crises. In case of a crisis, IMF provides temporary loans and advice for curing the disease.

The second world level institution is the World Bank. The core job of the World Bank has a structural dimension and consists in "helping developing countries and their people reach the goals by working with our partners to alleviate poverty. To do that we concentrate on building the climate for investment, jobs and sustainable growth, so that eco- 
nomies will grow, and by investing in and empowering poor people to participate in development." Nevertheless, given the strong social consequences of financial crises in developing countries, the World Bank also tries to strengthen architecture of the International Monetary System.

The third and the oldest institution is the Bank of International Settlements, $3^{\circ}$ which fosters international monetary and financial cooperation and serves as a bank for central banks. With the increase in the frequency of banking crises, its role for the prevention and management of such crises has been amplified. The Basel Committee on Banking Supervision, created in 1974 after the collapse of the Bankhaus Herstatt and composed by the G10 central bankers is the key group within the BIS. It stimulates the convergence of banking regulation and ensures that all financial institutions are supervised by common principles. Typically, it is expected that a more efficient and stricter regulation of the financial system would prevent third-generation crises. At the regional level, the European Central Bank also has a word to say. In the middle of the subprime crisis, ECB kept its right to increase or decrease liquidities on the market independent from the IMF or the Federal Reserve Bank. Similarly, the ECB's role in terms of supervisory competence is not clearly defined. The ambiguous Article 105 preserves European countries' sovereignty in terms of supervision, except if contagion and major crisis are expected.

Finally, at the national level, central banks may want to keep their prerogative in terms of crisis management. For example, the Bank of England, facing the possibility of a major crisis after the bankruptcy of Northern Rock, decided to act independently.

It is obvious, then, that these three levels of architecture are too complex and may sometimes lead to strong inefficiencies. In the case of the Russian crisis, the World Bank offered a 1.6 billion USD loan in December 1997, followed by a 22.7 billion USD loan by the IMF in July 2008. A joint action would have surely been more efficient to cure the Russian cold. Similarly, the recent subprime crisis has shown that the individual intervention of some central bank (the FED in this case) is useless if there is no cooperation with other institutions. Typically, in a second-generation case, where market pessimism is involved, only a common reaction may restore the confidence of the markets. It would nevertheless be unfair to say that coordination does not exist at all. Some attempts at greater coordination have been proposed: ECB has an observer status within the board of directors of the IMF, the IMF council, and in September 1998, the Financial Sector Liaison Committee (FSLC)

30 It was founded in 1930. 
was created between the IMF and the World Bank. Recent responses to the subprime crisis have been coordinated across these institutions. Nevertheless, cooperation is still far from perfect. For instance, the Bank of England refused to join the last common intervention of the ECB and the FED.

\section{Conclusion}

It is obvious that the "financial crisis" disease will remain a hot topic in the future. My objectives as a professor in International Monetary Economics would consist in participating in better prevention, understanding and management of these diseases.

I have no doubt that new modeling techniques and more efficient econometric techniques would help us to better isolate contagions of globalization and provide more stringent Early Warning Systems, and these would lead to a more efficient organization of the International Monetary structure.

\section{Words of thanks}

Now that this lecture comes to an end, I would like to take this rare opportunity to thank all the persons who believe and help me in reaching this position of Professor in International Monetary Economics at University Maastricht.

Voorst een woord van dank aan het Faculteitsbestuur van de Faculteit der Economische Wetenschappen en Bedrijfskunde van de Universiteit Maastricht voor mijn benoeming tot hoogleraar Internationale Monetaire Economie.

As I wrote it ten years ago in my PhD dissertation, I do not see research as an isolated monologue between a brain and a pen, but instead as a group emulation enriched by exchanges, criticisms and improvements. This idea, which goes far beyond the restricted professional area, is without any doubts inherited from my ancestors. Woodworkers and "Compagnons du Devoir", they were beginning their career with a long "tour de France", confronting their techniques with new ones, learning different cultures and using regional specificities as a strength and not a drawback. It is then not surprising that the beginning of my career looks like an initiatic travel, passing by the Université Paris I Panthéon 
Sorbonne, Maastricht University, l'Université Catholique de Louvain and the Humboldt Universität zu Berlin. I met at each stop wonderful people and discovered fascinating languages and cultures.

Maastricht University has to this respect a particular place. Young French PhD student I arrived in the department of Quantitative Economics in February 1997 for a six month Human Capital Mobility grant from the European Commission. It was for me a revelation and I quickly realized that there would be no way back to Paris. I am thus very grateful to all the members of this department at this time and particularly to Franz Palm.

\section{Cher Franz,}

Quand j'ai préparé ces remerciements je me suis rendu compte que ton nom apparaissait à toutes les étapes de ma carrière: depuis mon premier séjour à Maastricht, en passant par ma défense de thèse, mon séjour à Berlin, mon retour à Maastricht, jusqu'au comité d'évaluation pour cette chaire. Je tiens à te remercier pour la confiance que tu as placée en moi et te dire tout mon respect sur le plan professionnel et mon admiration pour ta simplicité et ton humilité.

Je suis ensuite parti pour Louvain-la-Neuve où Henri Sneessens a accepté de devenir mon directeur de thèse. Sans son aide ainsi que celle de Vincent Bodart et de Fati Shadmann-Meta, je n'aurai pas pu obtenir mon doctorat. J'ai pu aussi au cours de ce premier séjour en Belgique apprécier pleinement la vie estudiantine et aussi me rendre compte des possibles liens entre la recherche académique et le monde des affaires.

My choice for the academic career was nevertheless confirmed during my period at the Humboldt Universität zu Berlin. I realised how stimulating and fascinating life could be working in a group of top level researchers. I worked and learned a lot. I am thus very grateful to Helmut Lütkepohl and the other members of the Institüt für Statistics und Ökonometrie. I also benefited from the great moments I shared with my roommate Luis Alberiko Gil-Alana, from which result a strong friendship. I also would like to address special thanks to Jörg Breitung.

\section{Lieber Jörg,}

Ich werde versuchen mich auf Deutsch zu äussern, eine Sprache die wir beide wissen sehr zu schätzen, und die ich einmal gesprochen habe. 
Es ist mir schwierig dir meine Dankbarkeit auszudrücken. Du hast mir unglaublich viel geholfen als ich in Berlin war, sowohl in der professionellen Sicht, als auch in das Persönliche. Es könnte neben einen Glass von Bier oder Wein, bei einem Abendessen, im Büro oder im Lac Leman sein, aber ich habe von deine geniale Ideen und Bemerkungen immer gelernt. Für mich sind deine Arbeitskapazität und deine Kreativität immer ein unerreichbares Vorbild gewesen. Ich bin stolz darauf dich einen Freund nennen zu können. Ich habe grosse Freude an unserer Zusammenarbeit, und ich bin der festen Zuversicht, dass sie auch in der Zukunft fortlaufen wird, beziehungsweise versrpreche ich dir, dass ich in der Zukunft schneller sein werde.

In 2001 kwam ik terug bij de afdeling economie van de Faculteit derEconomische Wetenschappen en Bedrijfskunde van de Universiteit Maastricht. Dankzij Clemens Kool en Joan Muysken voelde ik mij alsof ik was thuisgekomen in een nieuwe tak van familie die ik enkele jaren daarvoor had verlaten. Ik wil de huidige en de voormalige leden van de 'Money' groep alsmede de leden van de 'International knowledge-' en de 'labor' groep, met wie ik een sterke band heb, bedanken. Ik wil ook een word van dank aan Sylvia Beenen, Fleur Keune and Sylvana de Sanctis zeggen voor de bijzonder efficiënte en altijd plezierige secretariële ondersteuning en samenwerking.

I would also like to thank all my co-authors: Jaap Bos, Allard Bruinshoofd, Michel Beine, Jeroen van den Berg, Vincent Bodart, Jörg Breitung, Gilbert Colletaz, Gianluca Cubadda, Arnaud Dupuy, Claire Economidou, Luis Gil-Alana, Alain Hecq, Christophe Hurlin, Clemens Kool, Olivier Lohest, Helmut Lütkepohl, Hans Manner, Joan Muysken, Jan Piplack, Katharina Raabe, Stefan Straetmans, Sessi Tokpavi, Jean-Pierre Urbain, Tom van Veen, Willem Verschoor and Robert Vermeulen. I realize that the list is quite long but all of them have learned me a lot. To their side, doing research looses its constraining aspect and becomes a real pleasure, like testing a good wine between friends during a summer evening.

Producing research constitutes one side of my life, but transmitting it is also a fascinating activity. Students can be provocative, even annoying, but after all they constitute a challenge, leading to improve and strengthen scientific reasoning and communication. This positive feedback is reinforced by the Problem Base Learning (PBL) system 
implemented at Maastricht University. The teacher is no more a tape in front of an auditorium, but can interact with the students. I really benefit from it and would like to thank my former students as well as the promoters of the PBL system.

Some students have a special place for me, in stimulating, challenging and avoiding me to sleep some nights. I mean the PhD students: Jan Piplack, Jeroen van den Berg, Robert Vermeulen, Chico Blasques and Norbert Metiu. I owe them a lot and despite my grey hairs I feel young at their sides.

Chers parents,

Je voudrais vous remercier pour tout ce que vous m'avez apporté et sans quoi je ne serai pas ce que je suis aujourd'hui. En particulier, vous m'avez appris l'importance du travail, de la connaissance et de l'humilité. Je vous remercie aussi d'avoir respecté mon choix pour cette profession exigeante et par moment incertaine. Vous m'avez toujours soutenu dans les moments difficiles, même si je sais que vous auriez préféré que je travaille en France et peut-être dans un secteur d'activité moins aléatoire.

Chère Anne, Chers Nathan et Erin,

J'espère que ce discours vous a donné une idée plus précise du sujet des mes recherches et que maintenant vous connaissez la raison pour laquelle à certains moments j'ai la tête dans les nuages. Mais je tiens à vous dire que je redescendrai toujours sur terre, car vous êtes ce que j'aime par-dessus tout.

Ik heb gezegd 


\section{References}

Allen, F.and D. Gale (1998) "Optimal Financial Crises," Journal of Finance, American Finance Association, vol. 53(4), 1245-1284.

Goldfajn, I. and D. Baig (1998) "Monetary Policy in the Aftermath of Currency Crises: The Case of Asia"

Bayoumi, T., G. Fazio, M. Kunan and R. McDonald (2003) "Fatal Attraction: A new Measure of Contagion." IMF Working Paper 03/80.

Berg, A. and C. A. Pattillo (1998) "Are Currency Crises Predictable? A Test," IMF Working Paper No. 98/154

Boinet, V., O. Napolitano and N. Spagnolo (2002). "Are currency crises self-fulfilling? the case of Argentina,» Economics and Finance Discussion Papers 02-26, Economics and Finance Section, School of Social Sciences, Brunel University.

Bordo, M. D., B. Eichengreen, D. Klingebiel and M. S. Martinez-Peria (2001) „Financial crises: lessons from the last 120 years“, Economic Policy.

Breitung, J. and B. Candelon (2005). "Purchasing Power Parity during Currency Crises: A Panel Unit Root Test under Structural Breaks,» Review of World Economics (Weltwirtschaftliches Archiv), vol. 127(1), pages 124140.

Breitung J. and B. Candelon (2008a) "Testing for Multistep Causality», Mimeo Maastricht University.

Breitung J. and B Candelon (2008b) "Investigating the Third-effect Country in the Transmission of the Crises", Mimeo Maastricht University.

Bruinshoofd, A., B. Candelon and K. Raabe (2008). "Banking Sector Strength and the Transmission of Currency Crises,» forthcoming in Open Economies Review 
Calvo, S. and C.M. Reinhart (1995). "Capital Inflows to Latin America: Is there Evidence of Contagion Effects?" in Guillermo A. Calvo, Morris Goldstein, and Eduard Hochreiter, eds.: Private Capital Flows to Emerging Markets After the Mexican Crisis (Institute for International Economics, Washington, DC).

Candelon, B., J. Piplack and S. Straetmans (2008) "On Measuring Synchronization of Bulls and Bears: the Case of East Asia,» Journal of Banking and Finance 32, 1022-1035.

Chang, R. and A. Velasco (1998) «The Asian Liquidity Crisis, " NBER Working Papers 6796, National Bureau of Economic Research, Inc.

Dell'Ariccia, G., E. Detragiache and R. Rajan (2008) "The Real Effect of Banking Crises," Journal of Financial Intermediation, vol. 17(1), pages 89-112.

Demirgüc,-Kunt, A. and E. Detragiache (1998) "The Determinants of Banking Crises in Developing and Developed Countries," IMF Staff Papers 45(1), 81-109.

Detragiache, E. and A. Spilimbergo (2001). "Crises and Liquidity - Evidence and Interpretation," IMF Working Papers 01/2, International Monetary Fund.

Eichengreen, B.J., Rose, A. K. and Wyplosz, C. (1996). "Contagious Currency Crises". NBER Working Paper No. W5681.

Forbes, K. and R. Rigobon (2002). "No Contagion, only Interdependence: Measuring Stock Market Co-Movements.," Journal of Finance 57 (5), 2223-2261.

Glick, R. and M. Hutchinson (1999). "Banking and Currency Crises; How Common are Twins?" Proceedings, Federal Reserve Bank of San Francisco.

Glick, R. and A. Rose (1999) "Contagion and Trade: Why are Currency Crises Regional?," Journal of International Money and Finance, 18(4), 603-617. 
Hutchison, M. M. and Noy, I. (2006) "Sudden stops and the Mexican wave: Currency crises, capital flow reversals and output loss in emerging markets," Journal of Development Economics, vol. 79(1), 225-248.

Kaminsky, G., S. Lizondo and C. Reinhart (1998) "Leading Indicators of Currency Crisis," IMF Staff Papers, International Monetary Fund, vol. 45(1), 1.

Keynes, J. M. (1936) "The General Theory and Employment, Interest and Money," Macmillan, New York.

Kindleberger, C. P. (2000) "Comparative Political Economy, A Retrospective," The MIT Press, Massachusetts.

King M. and S. Wadhwani (1990) "Transmission of Volatility between Stock Markets." Review of Financial Studies 3: 5-33.

Krugman, P. (1999) "Balance Sheets, the Transfer Problem, and Financial Crises," International Tax and Public Finance 6(4), 459-472.

Kumar, M. S., P. R. Masson and M. Miller (2000) "Global Financial Crises Institutions and Incentives," IMF Working Papers 00/105, International Monetary Fund

Manner, H. and B. Candelon (2008) "Testing for Contagion: A New TimeVarying Copula Approach" Mimeo Maastricht University.

Masson, P.R. (1999) "Contagion: Monsoonal Effects, Spillovers, and Jumps Between Multiple Equilibria", in Agnor, P., M. Miller and D. Vines (eds), The Asian Crises: Causes, Contagion and Consequences, Cambridge: Cambridge University Press.

McKinnon, R. and H. Pill (1996) "Credible Liberalisations and International Capital Flows. The Overborrowing Syndrome”, in T. Ito and A. Krueger, (ed.), "Financial Regulation and Integration in East Asia", Chicago: University of Chicago Press.

Obstfeld, M. (1994) "The Logic of Currency Crises", NBER Working Paper, 4640, Cambridge, Mass.: National Bureau of Economic Research. 
Pescatori, A. and A.N. R. Sy (2007) "Are Debt Crises Adequately Defined?," IMF Staff Papers, vol. 54(2), 306-337.

Rigobon, R. (1999) "Identification through Heteroskedasticity: Measuring "Contagion" between Argentinean and Mexican Sovereign Bonds," MIT mimeo, December.

Tudela (2004) "Explaining currency crises: a duration model approach," Journal of International Money and Finance, vol. 23(5), 799-816.

van den Berg, J.(2008) Early Warning System for financial crisis, PhD thesis Maastricht University (in preparation)

van den Berg, J., B. Candelon and J.-P. Urbain (2008). "A cautious Note on the Use of Panel Models to Predict Financial Crises" forthcoming in Economics Letters

Van Rickenghem, C. and Weder, B. (2001) "Source of Contagion. Is it Finance or Trade?" Journal of International Economics 54, 293-308. 

